\title{
WANITA KARIR DALAM PERSPEKTIF HUKUM ISLAM
}

\author{
Oleh \\ Adanan Murroh Nasution \\ Dosen Fakultas Syariah dan Ilmu Hukum IAIN Padangsidimpuan \\ Email: adananmurrohnasution@iain-padangsidimpuan.ac.id
}

\begin{abstract}
Abstrac
This paper describes about women who work outside the home, known as career women, as the main focus of the problem in this paper is how is the view of Islamic law towards career women. So to answer this problem the authors use the literature study method by tracing the opinions of scholars about career women from various literatures.

The findings, that in Islam some scholars allow women to work outside the home to become career women, namely women who are able to manage their lives to achieve success, both in professional life (work in the office) and in fostering their households.
\end{abstract}

Kata Kunci; Wanita, Karir, Perspektif, Hukum, dan Islam

\section{A. Pendahuluan}

Kebutuhan hidup dewasa ini yang semakin tinggi memaksa para wanita untuk bekerja dan meninggalkan rumah demi membantu suami dalam memenuhi kebutuhan hidup dirinya dan keluarganya. Seiring perkembangan zaman saat ini masyarakat menilai bahwa pekerjaan wanita tidak hanya membantu suaminya mengurus rumah tangga saja akan tetapi mereka bisa menuntut ilmu setinggi-tingginya dan bekerja untuk mengaktualisasi keterampilan dan pendidikannya. ${ }^{1}$

Islam sendiri sebagai agama yang adil telah menetapkan hak yang hilang dari wanita sebelum kedatangan Islam dan setelahnya. Islam menjamin bahwa wanita berhak memiliki harta dan kepemilikannya atas harta tersebut diakui secara penuh termasuk dalam hal harta warisan sebagaimana ditegaskan dalam al-Qur'an pada surah an-Nisa' ayat 7 yang berbunyi sebagai berikut :

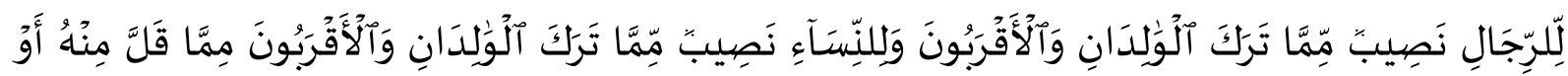

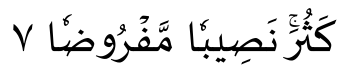


Artinya:

"Bagi orang laki-laki ada hak bagian dari harta peninggalan ibu-bapa dan kerabatnya, dan bagi orang wanita ada hak bagian (pula) dari harta peninggalan ibu-bapa dan kerabatnya, baik sedikit atau banyak menurut bahagian yang telah ditetapkan" $\{$ Qs. an-Nisa'/4:7\}

Perkembangan dunia menyajikan hal lain untuk wanita, yaitu jaminan untuk sukses secara finansial menjemput impian dengan pekerjaan yang prestise (posisi yang tinggi dalam dunia pekerjaan) yang selanjutnya memberikan predikat kepada wanita dengan gelar wanita karier. Saat ini, segala jenis pekerjaan sudah bisa ditempati kaum hawa mulai dari pekerjaan yang mengerahkan pemikiran sampai pekerjaan yang mengandalkan otot, sekalipun sebagian besar kaum perempuan ingin menjadi ibu rumah tangga yang baik akan tetapi ketika masalah finansial menghadang keberlangsungan hidup berumah tangga dan mengharuskan perempuan ikut mengais rezeki dengan segala upaya menjadikan perempuan keluar rumah dan bekerja. ${ }^{2}$

Maka ketika seorang ibu rumah tangga menjadi wanita karir bahkan waktunya lebih banyak dihabiskan untuk bekerja sehingga mengabaikan suami dan anak-anaknya, yang kemudian memunculkan permasalahan pertengkaran yang pada akhirnya berdampak pada perceraian suatu peristiwa yang sangat dibenci oleh Allah SWT. Maka lewat tulisan ini penulis ingin memberikan penjelasan mengenai wanita karier dalam pandangan hukum Islam.

\section{B. Wanita Karir Dalam Perspektif Hukum Islam}

Dalam ajaran Islam, wanita sangat dipandang mulia sebab memiliki peran dan tugasnya dalam masyarakat begitu mulai yaitu sebagai ibu dan isteri, sebagai seorang isteri tentunya seorang isteri memiliki kewajiban pada suaminya untuk mengurus diri suaminya, rumah tangga dan anak-anaknya. Maka dalam ajaran Islam sangat menganjurkan seorang isteri untuk tetap tinggal dalam rumah sebagaimana disebutkan dalam sebuah ayat al-Qur' an yang berbunyi sebagai berikut:

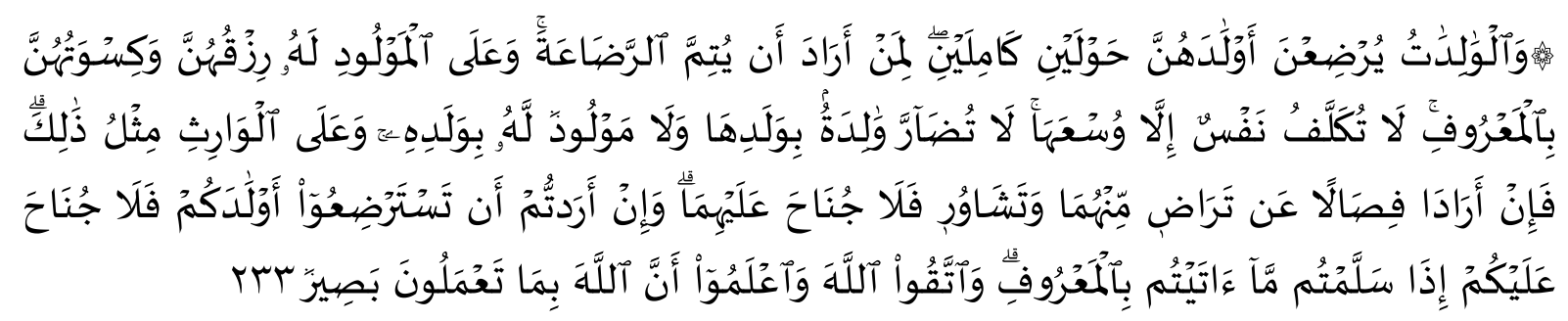

Artinya:

"Para ibu hendaklah menyusukan anak-anaknya selama dua tahun penuh, yaitu bagi yang ingin menyempurnakan penyusuan. Dan kewajiban ayah memberi makan dan pakaian kepada para ibu dengan cara máruf. Seseorang tidak dibebani melainkan menurut kadar kesanggupannya. Janganlah seorang ibu menderita kesengsaraan karena anaknya dan seorang ayah karena anaknya, dan warispun berkewajiban demikian. Apabila keduanya ingin 
menyapih (sebelum dua tahun) dengan kerelaan keduanya dan permusyawaratan, maka tidak ada dosa atas keduanya. Dan jika kamu ingin anakmu disusukan oleh orang lain, maka tidak ada dosa bagimu apabila kamu memberikan pembayaran menurut yang patut. Bertakwalah kamu kepada Allah dan ketahuilah bahwa Allah Maha Melihat apa yang kamu kerjakan". \{Qs. al-Baqarah/2:233\}

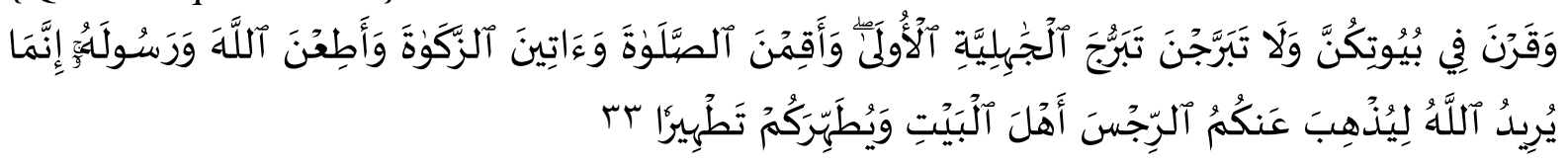

Artinya:

"dan hendaklah kamu tetap di rumahmu dan janganlah kamu berhias dan bertingkah laku seperti orang-orang Jahiliyah yang dahulu dan dirikanlah shalat, tunaikanlah zakat dan taatilah Allah dan Rasul-Nya. Sesungguhnya Allah bermaksud hendak menghilangkan dosa dari kamu, hai ahlul bait dan membersihkan kamu sebersih-bersihnya" \{Qs. al-Ahzab/33:33\}

Kendatipun demikian, tidak ada satupun petunjuk maupun ketetapan dalam ajaran Islam yang melarang wanita untuk bekerja diluar apalagi pekerjaan tersebut membutuhkan peran dan penanganan seorang wanita seperti pekerjaan merawat dan mengajar anak-anak. Sebab laki-laki dan perempuan sama-sama memiliki keterampilan tersendiri di bidangnya masing-masing, ${ }^{3}$ dengan kata lain keduanya memiliki kelebihan masing-masing sebagaimana ditegaskan Allah SWT dalam surah ani-Nisa' ayat 32 yang berbunyi sebagai berikut :

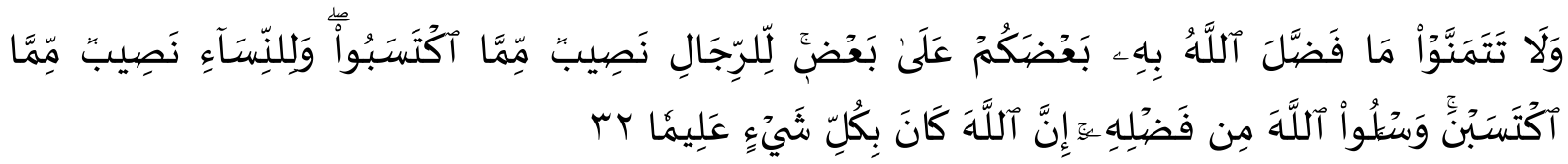

Artinya:

"Dan janganlah kamu iri hati terhadap apa yang dikaruniakan Allah kepada sebahagian kamu lebih banyak dari sebahagian yang lain. (Karena) bagi orang laki-laki ada bahagian dari pada apa yang mereka usahakan, dan bagi para wanita (pun) ada bahagian dari apa yang mereka usahakan, dan mohonlah kepada Allah sebagian dari karunia-Nya. Sesungguhnya Allah Maha Mengetahui segala sesuatu'. \{Qs. an-Nisa'/4: 32$\}$

\section{Pandangan Ulama Yang Membolehkan Wanita Karir}

Sebagian ulama ada yang membolehkan kaum wanita untuk bekerja di luar rumah guna mencari nafkah demi mendapatkan kehidupan yang layak, dengan berlandaskan atau berdasarkan dua alasan sebagai berikut :

1. Sebuah rumah tangga memerlukan banyak biaya untuk kebutuhan sehari-hari, maka bagaimana menjalankan fungsi keluarga sementara penghasilan suami belum begitu memadai, bisa jadi dikarenakan suami sedang sakit atau meninggal sehingga mau tidak mau seorang wanita harus mencari nafkah bagi dirinya sendiri maupun anak-anaknya.

Maka menurut sebagaian ulama, bahwa seorang wanita boleh bekerja di luar rumah apabila memang ada sesuatu yang sangat mendesak untuk berkarirnya wanita tersebut 
diluar rumah dan hal ini diperbolehkan. Namun harus dipahami bahwa sebuah kebutuhan yang mendesak ini harus ditentukan dengan kadarnya yang sesuai sebagaimana sebuah kaidah fikkiyah yang masyhur. Dan kebutuhan yang mendesak ini. Misalnya karena suaminya atau orang tuanya meninggal dunia atau keluarganya sudah tidak bisa memberi nafkah karena sakit atau lainnya, sedangkan negara tidak memberikan jaminan pada keluarga semacam mereka. Lihatlah kisah yang difirmankan Allah WT dalam surat alQashash ayat 23 dan 24 yang berbunyi sebagai berikut :

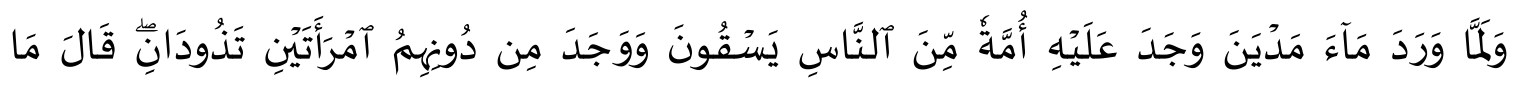

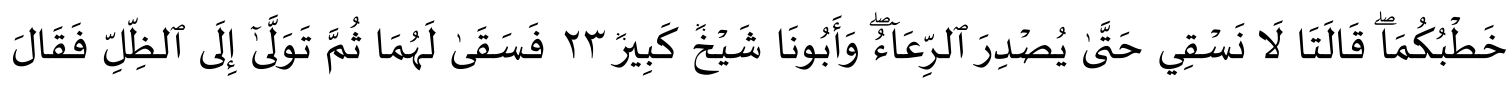

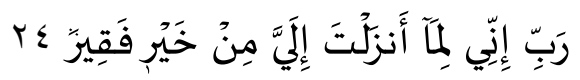

Artinya:

${ }^{623}$ Dan tatkala ia sampai di sumber air negeri Madyan ia menjumpai di sana sekumpulan orang yang sedang meminumkan (ternaknya), dan ia menjumpai di belakang orang banyak itu, dua orang wanita yang sedang menghambat (ternaknya). Musa berkata: "Apakah maksudmu (dengan berbuat at begitu)?" Kedua wanita itu menjawab: "Kami tidak dapat meminumkan (ternak kami), sebelum pengembala-pengembala itu memulangkan (ternaknya), sedang bapak kami adalah orang tua yang telah lanjut umurnya". “24. Maka Musa memberi minum ternak itu untuk (menolong) keduanya, kemudian dia kembali ke tempat yang teduh lalu berdoa: "Ya Tuhanku sesungguhnya aku sangat memerlukan sesuatu kebaikan yang Engkau turunkan kepadaku". \{Qs. alQashash/28:23-24\}

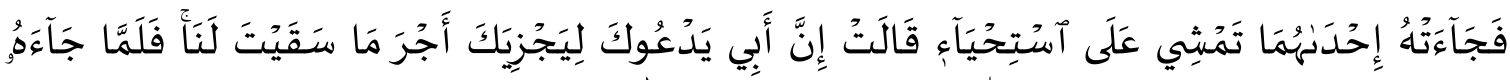

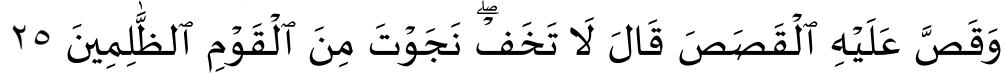

Artinya:

"Kemudian datanglah kepada Musa salah seorang dari kedua wanita itu berjalan kemalumaluan, ia berkata: "Sesungguhnya bapakku memanggil kamu agar ia memberikan balasan terhadap (kebaikan)mu memberi minum (ternak) kami". Maka tatkala Musa mendatangi bapaknya (Syu'aib) dan menceritakan kepadanya cerita (mengenai dirinya), Syu aib berkata: "Janganlah kamu takut. Kamu telah selamat dari orang-orang yang zalim itu". \{Qs. al-Qashash/28: 25\}

Apabila diperhatikan, pada kata wanita di atas tepatnya pada kata "sedang bapak kami adalah orang tua yang telah berumur lanjut" menunjukkan bahwa keduanya melakukan perbuatan tersebut karena terpaksa, disebabkan orang tuanya sudah lanjut dan tidak bisa melaksanakan tugas tersebut. 
2. Masyarakat memerlukan bantuan dan peran wanita untuk melaksanakan tugas tertentu yang hanya bisa dikerjakan seorang wanita seperti profesi sebagai perawat, dokter, guru dan pekerjaan lain yang sesuai dengan kodrat wanita.

Para ulama yang membolehkan wanita karir ini berlandaskan pada sebuah hadis, bahwa Rasulullah SAW sendiri pun tidak pernah melarang kaum wanita untuk melakukan pekerjaan di luar rumah, hal ini sebagaimana termaktub dalam beberapa riwayat yaitu "Dari Mu'âdh ibn Sa'ad diceritakan bahwa budak perempuan Ka'ab ibn Malik sedang menggembala kambingnya di Bukit Sala', lalu ada seekor kambing yang sekarat. Dia sempat mengetahuinya dan menyembelihnya dengan batu. Perbuatannya itu ditanyakan kepada Rasulullah SAW. Beliau menjawab, "Makan saja!.” \{HR. Bukhari\}

Tidak hanya itu, pada masa Rasulullah SAW para wanita banyak yang bekerja di luar rumah seperti membantu orang yang melahirkan semacam dukun bayi atau bidan pada saat ini, dimasa itu wanita ada juga yang mengkhitan anak-anak wanita. Apalagi di era zaman sekarang ini tentu banyak profesi-profesi yang sangat membutuhkan peran wanita yaitu dokter wanita spesialis kandungan, perawat saat bersalin, tenaga pengajar yang khusus mengajar wanita dan profesi-profesi lainnya. Termasuk peran para wanita di zaman Rasulullah SAW ketika dalam kondisi perang yaitu memberikan minum dan mengobati orang-rang yang terluka, inilah yang sering dilakoni Ummu Sulaim dan beberapa wanita Anshor kala itu, bahkan dalam catatan sejarah tercatat bahwa sebagian dari isteri Rasulullah SAW juga menjadi berprofesi sebagai wanita karier, diantaranya:

a) Siti Khadijah

Pertama adalah isteri Rasulullah SAW yang bernama Siti Khadijah r.a, yang dalam catatan sejarah bukanlah sosok wanita yang hanya berdiam diri serta bersembunyi di dalam kamarnya, tetapi sebaliknya Siti Khadijah adalah seorang wanita yang aktif dalam dunia bisnis. Bahkan sebelum Rasulullah SAW menikahinya Siti Khadijah r.a adalah seorang pembisnis tangguh di negeri Syam dan setelah menikah dengan Rasulullah SAW Siti Khadijah pun tidak lantas berhenti dari aktifitasnya sebagai pembisnis melainkan tetap menjalankan bisnisnya.

Bahkan harta hasil jerih payah bisnis Siti Khadijah r.a ini kala itu sangat banyak menunjang dakwah di masa awal Islam, sebab pada masa itu belum ada sumber-sumber dana penunjang dakwah yang bisa diandalkan, hanya bersumber dari kocek seorang donatur setia yaitu isteri Rasulullah SAW Siti Khadijah r.a sosok pebisnis kondang. 
Sebagai seorang pebisnis tentu Siti Khadijah r.a tidak mungkin terlepas dari dunia luar sebab bagaimana bisa Siti Khadijah r.a menjalankan usahanya apabila tidak memiliki akses informasi. Namun sekalipun Siti Khadijah r.a pembisnis ia tetap sosok tipe wanita rumahan yang tidak lupa akan kewajibannya dalam rumah tangga. Maka dalam sejarah tercatat bahwa Siti Khadijah r.a tidak hanya sukses dalam bisnisnya namun Siti Khadijah r.a juga berhasil mendidik anak-anaknya.

b) Siti Aisyah

Kedua, isteri Rasulullah SAW yang bernama Siti Khadijah r.a juga merupakan wanita karir yang cerdas, muda dan cantik yang kiprahnya di tengah masyarakat tidak diragukan lagi, yang mana posisinya sebagai seorang isteri tidak menghalanginya dari aktif di tengah masyarakat. Semasa Rasulullah SAW masih hidup, Siti Aisyah r.a sering sekali ikut keluar Madinah bersama Rasulullah SAW dalam berbagai operasi peperangan. Kemudian setelah meninggalnya Rasulullah SAW Siti Aisyah r.a pun menjadi guru para shahabat yang memberikan penjelasan dan keterangan tentang ajaran Islam. Bahkan Siti Aisyah r.a pun tidak mau ketinggalan untuk ikut dalam peperangan, sehingga dalam sebuah peperangan disebut dengan perang unta (jamal) karena saat itu Siti Aisyah r.a menaiki seekor unta.

Dari kisah kedua isteri Rasulullah SAW di atas ini, memberikan pedomana bahwa seorang wanita karir harusnya harus memilih pekerjaan yang sesuai dengan tabi'at dan kodratnya sebagai wanita seperti dalam bidang pengajaran, kebidanan, menjahit dan lainlain serta mampu menyeimbangkan antara pekerjaan dan kewajibannya sebagai seorang isteri dan ibu dari anak-anaknya. maka sekalipun sebagian ulama membolehkan wanita bekerja di luar rumah, namun harus memenuhi persyaratan yang antara lain sebagai berikut :

1) Menutup aurat dengan hijab

Seorang wanita karir harus senantiasa menutup aurat, yaitu menutupi seluruh tubuhnya kecuali wajah dan telapak tangan sebab ini adalah merupakan amanah dari ayat al-Qur'an 'Dan katakanlah kepada perempuan-perempuan yang beriman supaya menyekat pandangan mereka (daripada memandang yang haram) dan memelihara kehormatan mereka dan janganlah mereka memperlihatkan perhiasan tubuh mereka, kecuali yang zahir daripadanya. Dan hendaklah mereka menutup belahan baju mereka dengan tudung kepala mereka“. \{Qs.al-Nur/24:31\}. 
Menutup aurat disini bertujuan supaya menjaga wanita yang berkarir di luar rumah dari fitnah dengn cara menutupi seluruh tubuhnya di hadapan laki-laki asing dan menjauhi semua hal yang berindikasi fitnah, baik di dalam berpakaian, berhias atau pun berwangi-wangian (menggunakan parfum).

Seorang wanita karir juga hendaknya memilih pekerjaan yang sama sekali tidak mendekati mudharat (hal-hal yang dapat membuat harga diri tergadai) seperti menghindari pekerjaan yang sampai larut malam atau pekerjaan yang selalu melaksanakan perjalanan ke luar kota jauh dari suami dan anak-anak.

2) Menghindari campur baur dengan pria

Seorang wanita yang bekerja di luar rumah, harus senantiasa menghindari tempattempat berbaurnya pria dan wanita, hal ini bertujuan untuk menjaga wanita dari fitnah karena wanita yang bekerja di luar rumah sangat rentan mengalami godaan dan dapat menyebabkan perselingkuhan dalam rumah tangga.

Maka, seorang wanita yang hendak berkarir dunia kerja harus meperhatikan dan memastikan bahwa tidak ada kholwat dan ikhtilat (campur baur) antara laki-laki dan wanita yang bukan mahram sebagaimana firman Allah SWT "Dan apabila kalian meminta pada mereka sebuah keperluan, maka mintalah dari balik hijab.” dan sabda Rasulullah SAW yang berbunyi sebagai berikut :

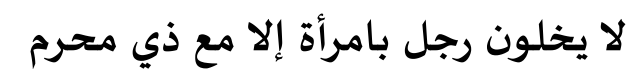

Artinya:

"Janganlah seorang laki-laki berdua-duaan dengan wanita kecuali bersama mahramnya."

Seorang wanita Muslimah agar terlihat istimewa dia harus dapat menjaga kehormatan dalam pergaulannya, harus membatasi diri dalam pergaulan. Seorang wanita apalagi yang sudah mempunyai suami harus hati-hati dengan sesuatu yang dapat mengakibatkan kemurkaan Allah SWT yang salah satunya adalah adanya batasan pergaulan dengan non muhrim.

3) Mendapat izin dari orangtua, wali atau suami bagi wanita yang telah menikah

Seorang wanita boleh bekerja di luar rumah apabila mendapat izin dari orangtua atau suaminya untuk wanita yang sudah menikah sebagaimana hal ini telah diamanahkan Allah SWT dalam al-Qur' an dalam surah al-Nisa' ayat 34 'Kaum lakilaki itu adalah pemimpin bagi kaum wanita, oleh karena Allah telah melebihkan sebahagian mereka (laki-laki) atas sebahagian yang lain (wanita), dan karena 
mereka (laki-laki) telah menafkahkan sebagian dari harta mereka. Sebab itu maka wanita yang saleh, ialah yang taat kepada Allah lagi memelihara diri ketika suaminya tidak ada, oleh karena Allah telah memelihara (mereka). Wanita-wanita yang kamu khawatirkan nusyuznya, maka nasehatilah mereka dan pisahkanlah mereka di tempat tidur mereka, dan pukullah mereka. Kemudian jika mereka mentaatimu, maka janganlah kamu mencari-cari jalan untuk menyusahkannya. Sesungguhnya Allah Maha Tinggi lagi Maha Besar”.

4) Tetap menjalankan kewajibannya di rumah

Untuk menjadi wanita karir dalam ajaran Islam memang tidak dilarang asal tidak melalaikan tugasnya sebagai seorang isteri atau ibu untuk mengurus rumah tangga atau keluarganya serta mendidik anak-anaknya. Maka seorang wanita karir harus jug memberikan perhatian dan waktu yang cukup pada keluarganya meskipun ia bekerja di luar rumah. Apalagi sampai ganti setir (memerintah suami) sebab menurut Abd alRabb bahwa seorang wanita tidak boleh menjadi pemimpin pria tetapi sebaliknya suamilah yang menjadi pemimpin dalam keluarga sebagaimana ditegaskan dalam alQur'an “Kaum laki-laki itu adalah pemimpin bagi kaum wanita, oleh Karena Allah Telah melebihkan sebahagian mereka (laki-laki) atas seba-hagian yang lain (wanita), dan Karena mereka (laki-laki) telah menaf-kahkan sebagian dari harta mereka”. \{Qs. An-Nisa/4:34\}.

Seorang wanita karir, sekalipun memiliki jabatan yang tinggi di tempat ia bekerja maka ia harus tetap mengerjakan kewajibannya sebagai ibu dan isteri bagi keluarganya karena kewajiban-kewajiban inilah adalah merupakan pekerjanya yang paling asasi. ${ }^{4}$

Kiprah kaum wanita cukup luas meliputi berbagai bidang, terutama yang berhubungan dengan dirinya sendiri, yang diselaraskan dengan Islam, dalam segi akidah, akhlak dan masalah yang tidak menyimpang dari apa yang sudah digariskan atau ditetapkan oleh Islam. Sebab Allah SWT menciptakan pria dan wanita dengan karakteristik yang berbeda-beda, maka secara sunnatullah (alami), laki-laki memiliki otot-otot yang kekar, kemampuan untuk melakukan pekerjaan yang berat, pantang menyerah, sabar dan lain-lain, cocok dengan pekerjaan yang melelahkan dan sesuai dengan tugasnya yaitu menghidupi keluarga secara layak. 
Maka dalam ajaran Islam bahwa seorang pria dituntut untuk menjamin kehidupan yang bahagia dan damai bagi wanita sehingga seyogianya seorang isteri tidak perlu untuk bekerja di luar rumah karena untuk kebutuhan keluarga sudah dibebankan ke atas pundak laki-laki untuk bekerja dengan giat dan bersusah payah demi menghidupi keluarganya. Maka apabila seorang wanita sudah menikah sang suamilah yang mengambil alih beban dan tanggung jawab terhadap semua urusannya serta memberikan nafkah anak-anaknya.

Sedangkan wanita memiliki kemampuan yang hanya dimiliki kaum wanita saja yaitu mengandung, melahirkan, menyusui, dan menyusuhi anak-anaknya sebagaimana disitir di dalam al-Qur'an 'Dan Kami perintahkan kepada manusia (berbuat baik) kepada dua orang ibu bapanya; Ibunya telah mengandungnya dalam keadaan lemah yang bertambah-tambah dan menyapihnya dalam dua tahun. Mengingat beratnya peran seorang wanita dalam sebuah rumah tangga, maka dalam ajaran Islam menghendaki supaya wanita-wanita yang melakukan pekerjaan atau wanita karir haruslah pekerjaan yang tidak bertentangan dengan kodrat kewanitaannya dan tidak mengungkung haknya di dalam bekerja.

Deskripsi di atas, menunjukkan bahwa agama Islam tidak pernah mensyariatkan untuk mengurung wanita di dalam rumah, sebagai bantahan dengan apa yang sering diasumsikan oleh sebagaian orang bahwa Islam terkesan mengurung wanita di dalam rumah. Termasuk keluar menuju masjid seorang wanita tidak dilarang sebagaimana sabda Rasulullah SAW pernah melarang orang yang melarang wanita mau datang ke masjid "Diriwayatkan dari Ibnu Umar dia berkata, Rasulullah SAW bersabda: "Janganlah kamu mencegah perempuanperempuan untuk pergi ke Masjid, sedangkan rumah mereka itu lebih baik bagi mereka”. "Dari Abdullah Bin Umar dia berkata, Rasulullah SAW bersabda: “Apabila salah seorang perempuan di antara kamu minta izin (untuk berjama'ah di masjid) maka janganlah mencegahnya". "Diriwayatkan dari Abu Hurairah dia berkata, sesungguhnya Rasulullah SAW bersabda: "Janganlah kamu mencegah kaum wanita untuk pergi ke masjid, tetapi hendaklah mereka keluar tanpa wangi-wangian.” Bukankah perjalanan dari rumah ke masjid serta dari masjid ke rumah sudah pasti akan bertemu dengan lawan jenis yang bukan mahram di perjanan tersebut.

Maka apabila ada orang yang mengatakan bahwa seorang wanita haram keluar rumah dan harus berkurung di dalam rumah, maka stetmen ini sesungguhnya bertentangan dengan apa yang terjadi di zaman Rasulullah SAW bahkan tindakan mengurung seorang wanita di dalam rumah saja tidak memperbolehkannya berkarya adalah sebuah perkara bid'ah yang sesat. Maka sesungguhnya dalam ajaran Islam seorang wanita boleh saja menjadi wanita karir 
namun tetap mengalokasikan waktunya untuk menjalin hubungan baik dengan suami dan anak-anak serta punya jadwal rutin silaturrahim dengan orangtua, mertua, maupun tetangga dekat. Dengan kata lain, seorang wanita karir yang hebat harus selalu menyeimbangkan kepentingan suami dan anak-anaknya dengan kegiatan-kegiatannya di kantor. ${ }^{5}$

\section{Pandangan Ulama Yang Melarang Wanita Karir}

Seorang wanita karir, di pagi hari harus sudah siap dengan pakaian rapi pergi menenteng tas menuju tempat kerja mereka masing-masing untuk menambah kebutuhan keluarga sehari-hari. ${ }^{6}$ Terlepas dari seorang isteri yang bekerja untuk membantuh suami dalam memenihi kebutuhan sehari-hari, tetapi ada juga seorang isteri memiliki penghasilan lebih besar dari suami. Disini sangat memungkinkan terjadi pertikaian, terkadang si isteri menjadi takabur (sombong) dengan apa yang dia dapatkan sehingga menghilangkan wibawa suaminya yang ujung-ujungnya mengakibatkan perceraian. ${ }^{7}$

Maka menurut sebagian ulama ada yang melarang wanita karir karena menurut mereka bahwa dengan bekerja seorang wanita diluar rumah maka akan ada banyak kewajibannya yang tertinggalkan. Misalnya melayani keperluan suami, mengurusi dan mendidik anak serta hal lainnya yang menjadi tugas dan kewajiban seorang isteri dan ibu. Mengingat semua pekerjaan ini sangat melelahkan sehingga membutuhkan perhatian khusus, sebab semua pekerjaan ini tidak mungkin terpenuhi seorang wanita terkecuali wanita yang benar-benar memberikan perhatian sepenuhnya untuk mengurus suami, keluarga, dan anak-anaknya. Pelarangan ini berdasarkan hadis Rasulullah SAW yang menjelaskan bahwa seorang suami diwajibkan untuk membimbing isterinya pada jalan yang benar sedang sang isteri diwajibkan untuk mentaati suaminya. Hal sebagaimana telah ditegaskan Rasulullah SAW dalam sebuah riwayat yang berbunyi sebagai berikut:

\section{ولهن عليكم رزقهن و كسـوتهن بالمعروف}

Artinya:

"Dan hak para isteri atas kalian (suami) agar kalian memberi mereka nafkah dan pakaian dengan cara yang ma'ruf."

Disisi lainnya, tempat wanita dijadikan di dalam rumah untuk mengurusi anak, mendidiknya, mempersiapkan keperluan suami serta urusan rumah tangga dan lainnya. Rasulullah SAW menggambarkan hal ini dalam sebuah sabda Rasulullah SAW yang berbunyi sebagai berikut : 


\section{والمرأة راعية في بيت زوجها ومسؤولة عن رعيتها}

Artinya:

"Dan wanita adalah pemimpin dirumah suaminya dan dia akan dimintai pertanggung jawaban atas yang dipimpinnya."

Tidak hanya sampai di situ, menurut sebagian ulama bahwa untuk menjadi wanita karir ada beberapa kemungkinan yang bersifat negative atau efek negatif yang dihadapi seorang wanita karir yang antara lain sebagai berikut $:^{8}$

1. Memberi pengaruh terhadap harga diri dan kepribadian seorang wanita

Banyak perkerjaan saat ini yang apabila ditekuni oleh kaum wanita akan mengeluarkanya dari kodrat kewanitaannya, menghilangkan rasa kefeminimannnya. Kerena memang banyak wanita yang sibuk bekerja diluar rumah hingga akhirnya tanpa disadarinya ia telah jauh keluar dari kodratnya sebagai wanita.

2. Memberi Pengaruh terhadap anak

Selain memberikan pengaruh terhadap kepribadiannya sendiri, juga memberikan pengaruh terhadap kepribadian anak yang antara lain sebagai berikut $:^{9}$

a. Anak kurang menerima kasih sayang, lembut belaian dari sang ibu, padahal anak sangat membutuhkannya untuk pengembangan kejiwaannya;

b. Kebanyakan wanita karir tidak bisa menyusui anaknya secara sempurna, tetapi sering sekali diganti dengan susu formula yang sudah barang tentu mengurangi daya tahan tubuh anak bahkan terkadang bisa membahaya bagi si anak;

c. Wanita karir dikarenakan kesibukannya sehingga tidak bisa mengawasianak-anaknya, kebanyakan wanita karir melimpahkan kewajibannya dalam menjaga anak kepada baby sister yang diberi upah, bahkan tidak jarang si anak mendapatkan prilakuan yang tidak baik dari oknum baby sister, yang paling tidak cara asuh baby sister dengan ibu kandung sudah pasti sangat berbeda, apalagi apabila baby sister tersebut memiliki riwayat pendidikan yang buruk. ${ }^{10}$

3. Memberi pengaruh terhadap hak suami

Seorang isteri yang pagi pergi kerja lalu sore pulang, maka sampai rumah ia akan tinggal melepas lelah. Lalu ketika suami pun pulang dari kerja maka suami juga tidak akan bisa memenuhi tugasnya sebagai kepala keluarga dikarenakan sudah kecapean bekerja di kantor.

4. Memberi pengaruhnya terhadap masyarakat dan perekonomian nasional 
Dengan masuknya kaum wanita dalam lapangan pekerjaan, sesungguhnya banyak mengambil bagian laki-laki yang seharusnya bisa mendapatkan pekerjaan namun terpaksa tidak menemukannya karena sudah diambil alih oleh kaum wanita. Hal ini akan meningkatkan jumlah pengangguran yang akan berakibat pada tindak kriminalitas sebagaimana terdapat dalam sabda Rasulullah SAW yang berbunyi sebagai berikut :

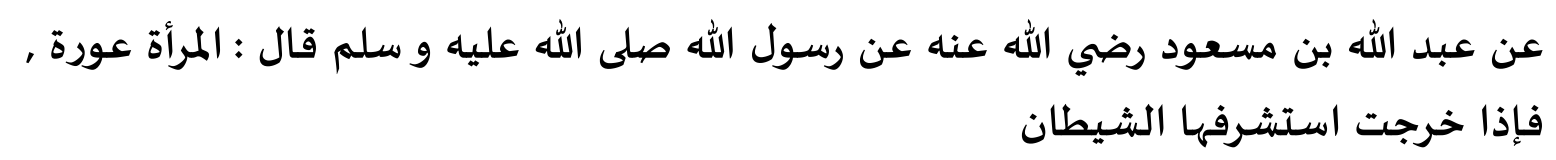

Artinya:

"Dari Abdullah bin Mas'ud r.a dari Rasulullah SAW bersabda : "Wanita itu aurat, apabila dia keluar maka akan dibanggakan oleh setan."

Riwayat di atas, menjelaskan tentang keluarnya wanita akan menjadikan para setan beristisyraf sehingga secara sekilas terkesan bahwa ketika seorang wanita keluar rumah, maka setan akan menaikinya dan akan menjadi sumber masalah baik bagi dirinya maupun bagi orang lain. Berdasarkan hadis inilah sebagian ulama yang melarang wanita karir untuk bekerja, namun sebagaian ulama yang lain ada yang meragukan keabsahan hadis ini.

Nashiruddin Al-Albani jelas menshahihkan hadis ini. Namun di sisi lain, tidak sedikit dari para ulama hadis yang mempersoalkan kedudukan hadis ini dengan alasan-alasan sebagai berikut :

a) Sebagian ahli hadis menyebutkan bahwa isnad hadis ini tidak tersambung kepada Rasululah SAW, isnadnya munqathi (terputus) karena Hubaib bin Abi Tsabit adalah merupakan salah seorang di antara mata rantai perawinya yang dikenal sebagai mudallis. Dia tidak mendengar langsung dari Ibnu Umar;

b) Sebagian ahli hadis lain menyebutkan bahwa hadis ini shahih terdapat dalam alausathnya Tabrani. Namun sebagaian ulama hadis lain menegaskan bahwa Mujam At-Thabrani Al-Awsath bukan kitab sunan, bahkan At-Thabarani sendiri tidak meniatkannya sebagai kitab shahih, beliau justru hanya sekedar mengumpulkan hadishadis yang ma'lul (bermasalah) supaya orang-orang tahu kemunkarannya. Sayangnya, ada orang-orang yang datang kemudian, malah menshahihkan hadis-hadis yang ada di dalamnya. Bahakan sebagaian ulama hadis menegaskan bahwa Imam At-Thabarani pada dasarnya tidak meriwayatkan hadis ini di dalam alawsathnya.

c) Sebagian orang juga menyebutkan bahwa Ibnu Khuzaemah menshahihkan hadis ini, namun sebagaian ahli hadis mengatakan bahwa Ibnu Khuzaemah sama sekali tidak pernah menshahihkan hadis ini. Bahkan Ibnu Khuzaemah menjelaskan illatnya, ia 
menuliskan kedalam sebuah judul Babu Ikhtiyari Shalatil Mar ah fi Baitiha ala Shalatiha fil Masjid, in tsabatal hadits. Kata penutup in tsabatal hadits ini sudah menunjukkan bahwa beliau belum memastikan keshahihan hadis ini.

Perdebatan antara para muhaddits tidak ada habisnya tentang keshahihan hadis ini, sebagian mengatakan itu hadis shahih tetapi sebagian ulama yang lain mengatakan bahwa hadis ini adalah hadis yang bermasalah. Namun yang jelas bahwa mengenai status wanita karir adalah dua pendapat ada yang melarang dan ada pula yang membolehkan dengan beberapa persyaratan yang dijelaskan pada pembahasan di atas. Karena dalam hukum sendiri antara laki-laki dan perempuan tidak pernah dibedakan tetapi sama dihadapan hukum. ${ }^{11}$

\section{E. Penutup}

Apabila diperhatikan lebih jauh, bahwa dampak wanita karir bagi keluarganya membawa dampak positif terhadap perkembangan ekonomi keluarga dan pemenuhan kebutuhan serta terbantunya masyarakat dengan peran serta wanita. Akan tetapi wanita karir yang terlalu sibuk mengejar karirnya dikhawatirkan tugas wanita sebagai isteri dan ibu akan terbengkalai. Dikarenakan sedikitnya waktu yang ia luangkan bersama keluarganya, seorang ibu yang terlalu larut di dalam pekerjaannya terkadang melupakan perannya dan membuat anak kurang mendapat perhatian sehingga banyak kasus anak yang terlibat perbuatan kriminal dan terjerumus narkoba.

Hakikat predikat wanita karier itu sebenarnya ada pada seorang wanita yang mampu mengelola hidupnya secara menyenangkan atau memuaskan, baik di dalam kehidupan profesional (pekerjaan di kantor) maupun di dalam membina rumah tangganya.

\section{End Note :}

${ }^{1}$ Elizahabet M. King Dkk, Pembangunan Perspektif Gender, penerj. T. Marlita (Jakarta: Dian Rakyat, 2005), hlm. 1.

${ }^{2}$ Khoiruddin Nasution, Fazlur Rahman Tentang Wanita, cet ke-1 (Yogyakarta: Zaffa, 2002), hlm. 20.

${ }^{3}$ Lies M. Marcoes, Wanita Islam Indonesia dalam Kajian Tekstual dan Kontekstual (Jakarta: INS, 1993), hlm. 20.

${ }^{4}$ Huzaemah T. Yanggo, Fiqh Wanita Kontemporer (Jakarta: Almawardi Prima, 2001), hlm. 93.

${ }^{5}$ Husein Muhammad, Figh Wanita Refleksi Kiai atas Wacana Agama dan Gender (Yogyakarta: LKIS, 2001), hlm. 159.

${ }^{6}$ M. Ali Hasan, Masail Fiqhiyah Al-Haditsah pada Masalah-Masalah Kontemporer Hukum Islam, (Jakarta: PT Raja Grafindo Persada, 1998), hlm. 193.

${ }^{8}$ Maisar Yasin, Wanita dalam Perbincangan, penerj. Ahmad Thabrano Mas'udi (Jakarta: Gema Insani Press, 1997), 7-30.

${ }^{9}$ Mansour Fakih, Analisis Gender dan Transformasi Sosial (Yogyakarta: Insist Press, 2008), hlm. 5-53.

${ }^{10}$ Nasaruddin Umar, Kodrat Perempuan dalam Islam (Jakarta: PT. Fikahati Aneska, 2000), hlm. 1-50. 
${ }^{11}$ Hendra Gunawan, “Sistem Peradilan Islam” Pada Jurnal el-Qanuniy: Jurnal Ilmu-Ilmu Kesyariahan dan Pranata Sosial Fakultas Syariah dan Ilmu Hukum IAIN Padangsidimpuan, Volume 5 Nomor 1 Edisi Januari-Juni 2019, hlm. 90-103.

\section{DAFTAR PUSTAKA}

Fakih, Mansour,. Analisis Gender dan Transformasi Sosial, Yogyakarta: Insist Press, 2008.

Gunawan, Hendra,. "Sistem Peradilan Islam” Pada Jurnal el-Qanuniy: Jurnal Ilmu-Ilmu Kesyariahan dan Pranata Sosial Fakultas Syariah dan Ilmu Hukum IAIN Padangsidimpuan, Volume 5 Nomor 1 Edisi Januari-Juni 2019.

Hasan, M. Ali,. Masail Fiqhiyah Al-Haditsah pada Masalah-Masalah Kontemporer Hukum Islam, Jakarta: PT Raja Grafindo Persada, 1998.

M. King, Elizahabet Dkk,. Pembangunan Perspektif Gender, penerj. T. Marlita, Jakarta: Dian Rakyat, 2005.

Marcoes, Lies M., Wanita Islam Indonesia dalam Kajian Tekstual dan Kontekstual, Jakarta: INS, 1993.

Muhammad, Husein,. Fiqh Wanita Refleksi Kiai atas Wacana Agama dan Gender, Yogyakarta: LKIS, 2001.

Nasution, Khoiruddin,. Fazlur Rahman Tentang Wanita, cet ke-1, Yogyakarta: Zaffa, 2002.

Umar, Nasaruddin,. Kodrat Perempuan dalam Islam, Jakarta: PT. Fikahati Aneska, 2000.

Yanggo, Huzaemah T., Fiqh Wanita Kontemporer, Jakarta: Almawardi Prima, 2001.

Yasin, Maisar,. Wanita dalam Perbincangan, penerj. Ahmad Thabrano Mas'udi, Jakarta: Gema Insani Press, 1997. 